Prepared in cooperation with the Colorado Water Conservation Board

\title{
Flood-Inundation Maps for the South Platte River at Fort Morgan, Colorado, 2018
}

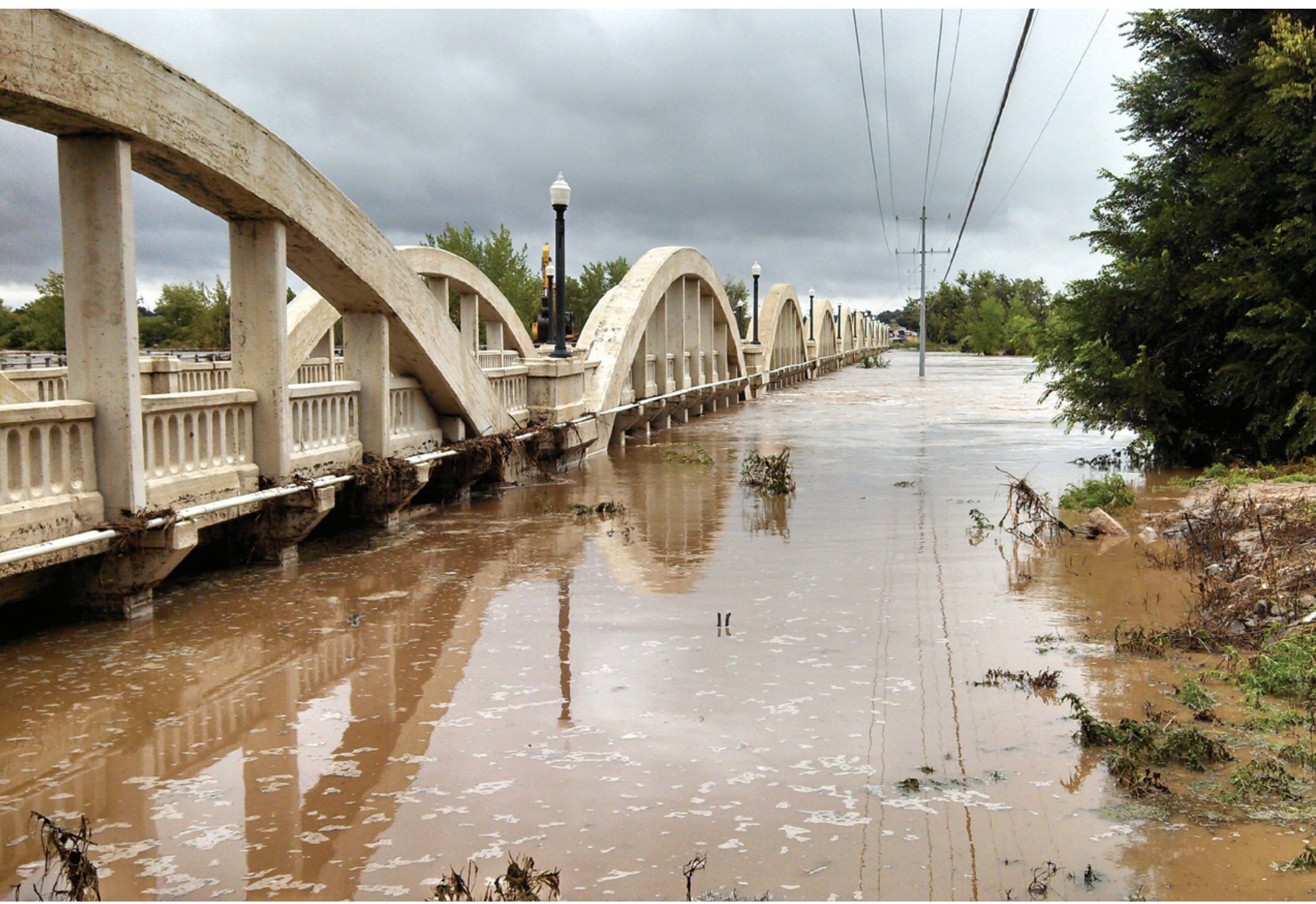

Scientific Investigations Report 2018-5114 
Cover. Front cover. Photograph of the South Platte River at Fort Morgan, Colorado, at the Colorado State Highway 52 bridge shortly after the crest of the September 15, 2013, flood; by John D. Miller, U.S. Geological Survey. Back cover. Photograph of the South Platte River at Fort Morgan, Colorado study area; looking upstream at the channel and left and right banks; by Michael S. Kohn, U.S. Geological Survey. 


\section{Flood-Inundation Maps for the South Platte River at Fort Morgan, Colorado, 2018}

By Michael S. Kohn and Thuy T. Patton

Prepared in cooperation with the Colorado Water Conservation Board

Scientific Investigations Report 2018-5114 


\section{U.S. Department of the Interior \\ RYAN K. ZINKE, Secretary}

\section{U.S. Geological Survey James F. Reilly II, Director}

\section{U.S. Geological Survey, Reston, Virginia: 2018}

For more information on the USGS - the Federal source for science about the Earth, its natural and living resources, natural hazards, and the environment-visit https://www.usgs.gov or call 1-888-ASK-USGS.

For an overview of USGS information products, including maps, imagery, and publications, visit https://store.usgs.gov.

Any use of trade, firm, or product names is for descriptive purposes only and does not imply endorsement by the U.S. Government.

Although this information product, for the most part, is in the public domain, it also may contain copyrighted materials as noted in the text. Permission to reproduce copyrighted items must be secured from the copyright owner.

Suggested citation:

Kohn, M.S., and Patton, T.T., 2018, Flood-inundation maps for the South Platte River at Fort Morgan, Colorado, 2018: U.S. Geological Survey Scientific Investigations Report 2018-5114, 14 p., https://doi.org/10.3133/sir20185114.

ISSN 2328-0328 (online) 


\section{Acknowledgments}

The authors wish to thank the Colorado Water Conservation Board for funding this study and Stephanie Dibetitto, in particular, for her vision and support throughout the study. The authors also thank the Cities of Fort Morgan and Brush for funding the operation and maintenance of the streamgage used for this study. The authors would like to thank Geoff Uhlemann at AECOM for graciously sharing topographic data that were used in this study. The authors are grateful to Pam Cherry of Morgan County; Joe Baumberger, Matt Harris, and Kyle Kembel of the Deuel and Synder Improvement Company; Bart Ginther of the Upper Platte and Beaver Canal Company; Dick Early of the Morgan Game and Fish Conservation Club; and Mike Erker for coordinating and providing access to the study area; without their efforts, this study would not have been possible. Special thanks are given to the National Weather Service for their continued support of the U.S. Geological Survey Flood Inundation Mapping Program. 


\section{Contents}

Acknowledgments .......................................................................................................................ii

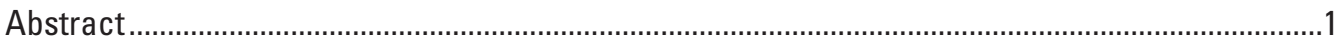

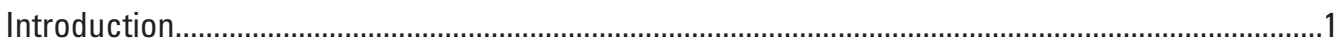

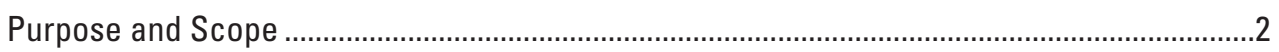

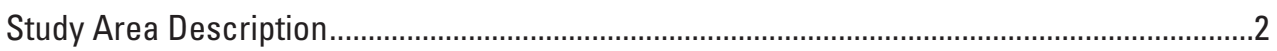

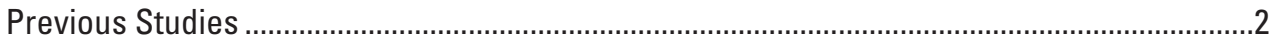

Creation of Flood-Inundation-Map Library …….......................................................................

Computation of Water-Surface Profiles.................................................................................

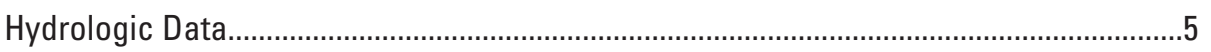

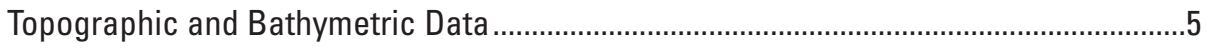

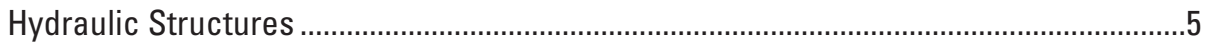

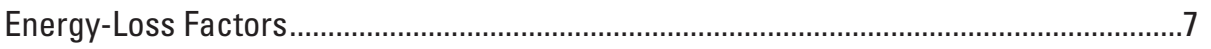

Hydraulic Model.............................................................................................................

Development of Water-Surface Profiles.........................................................................10

Development of Flood-Inundation Maps ...........................................................................10

Flood-Inundation Map Delivery .................................................................................10

Disclaimer for Flood-Inundation Maps .........................................................................10

Uncertainties and Limitations Regarding Use of Flood-Inundation Maps ......................12

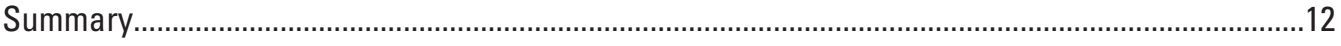

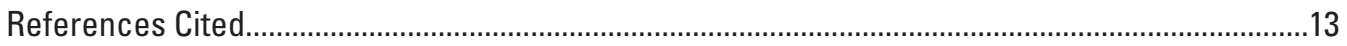

\section{Figures}

1. Map showing location of the study area for the U.S. Geological Survey (USGS) streamgage on the South Platte River at Fort Morgan, Colorado

2. Photograph of the South Platte River at Fort Morgan, Colorado study area; looking upstream at the channel and left and right banks; by Michael S. Kohn, U.S. Geological Survey

3. Map showing the study area for the U.S. Geological Survey (USGS) streamgage on the South Platte River at Fort Morgan, Colorado (streamgage number 06759500), including pressure transducers and cross sections used to simulate flood stage.

4. Flood-inundation map for the U.S. Geological Survey (USGS) streamgage South Platte River at Fort Morgan, Colorado (streamgage number 06759500), corresponding to a stage of 27 feet at the streamgage 


\section{Tables}

1. Information about the U.S. Geological Survey streamgage on the South Platte River at Fort Morgan, Colorado

2. Peak discharges from for the U.S. Geological Survey streamgage on the South Platte River at Fort Morgan, Colorado, (streamgage number 06759500) through water year 2015 .

3. Calibration of model to target water-surface elevations at the U.S. Geological Survey streamgage on the South Platte River at Fort Morgan, Colorado (streamgage number 06759500), and nine pressure transducer locations for four floods

4. Flood stages and corresponding discharges used to generate flood-inundation maps for the U.S. Geological Survey streamgage on the South Platte River at Fort Morgan, Colorado (streamgage number 06759500).

\section{Conversion Factors}

U.S. customary units to International System of Units

\begin{tabular}{lll}
\hline \multicolumn{1}{c}{ Multiply } & \multicolumn{1}{c}{ By } & \multicolumn{1}{c}{ To obtain } \\
\hline foot $(\mathrm{ft})$ & 0.3048 & meter $(\mathrm{m})$ \\
mile $(\mathrm{mi})$ & 1.609 & kilometer $(\mathrm{km})$ \\
square mile $\left(\mathrm{mi}^{2}\right)$ & 2.590 & square kilometer $\left(\mathrm{km}^{2}\right)$ \\
cubic foot per second $\left(\mathrm{ft}^{3} / \mathrm{s}\right)$ & 0.02832 & cubic meter per second $\left(\mathrm{m}^{3} / \mathrm{s}\right)$ \\
\hline
\end{tabular}

\section{Datum}

Vertical coordinate information is referenced to (1) stage, the height above an arbitrary datum established at a streamgage, and (2) elevation, the height above the North American Vertical Datum of 1988 (NAVD 88).

Horizontal coordinate information is referenced to the North American Datum of 1983 (NAD 83).

\section{Supplemental Information}

Water year is the 12-month period from October 1 through September 30. The water year is designated by the year in which it ends (WY). 


\section{Abbreviations}

$\begin{array}{ll}\text { AHPS } & \text { Advanced Hydrologic Prediction Service } \\ \text { CHAMP } & \text { Colorado Hazard Mapping Program } \\ \text { CWCB } & \text { Colorado Water Conservation Board } \\ \text { DEM } & \text { digital elevation model } \\ \text { GIS } & \text { geographic information system } \\ \text { GNSS } & \text { Global Navigation Satellite Systems } \\ \text { FEMA } & \text { Federal Emergency Management Agency } \\ \text { FIS } & \text { flood insurance study } \\ \text { ft } 3 \text { s } & \text { cubic feet per second } \\ \text { HEC-GeoRAS } & \text { Hydrologic Engineering Center GeoRiver Analysis System } \\ \text { HEC-RAS } & \text { Hydrologic Engineering Center River Analysis System } \\ \text { lidar } & \text { light detection and ranging } \\ \mathrm{n} & \text { Manning roughness coefficient } \\ \text { NAD 83 } & \text { North American Datum of 1983 } \\ \text { NAVD 88 } & \text { North American Vertical Datum of 1988 } \\ \text { NOAA } & \text { National Oceanic and Atmospheric Administration } \\ \text { NWIS } & \text { National Water Information System } \\ \text { NWS } & \text { National Weather Service } \\ \text { RTK } & \text { real-time kinematic } \\ \text { USACE } & \text { U.S. Army Corps of Engineers } \\ \text { USGS } & \text { U.S. Geological Survey }\end{array}$




\title{
Flood-Inundation Maps for the South Platte River at Fort Morgan, Colorado, 2018
}

\author{
By Michael S. Kohn' and Thuy T. Patton ${ }^{2}$
}

\section{Abstract}

In 2017, the U.S. Geological Survey (USGS), in cooperation with the Colorado Water Conservation Board (CWCB), studied floods in the historic record to produce a library of flood-inundation maps for the South Platte River at Fort Morgan, Colorado. Digital flood-inundation maps for a 4.5-mile (7.2-kilometers) reach of the South Platte River at Fort Morgan from Morgan County Road 16 to Morgan County Road 20.5, were created. The flood-inundation maps depict estimates of the areal extent and depth of flooding corresponding to selected water levels (stages) at the U.S. Geological Survey streamgage on the South Platte River at Fort Morgan (streamgage number 06759500).

Water-surface profiles were computed for the stream reach by means of a one-dimensional, step-backwater model. The September 15, 2013, and May 20, 2017, floods were used to calibrate the model, and the June 15, 2015, and May 29, 2017, floods were used to independently validate the model. Nine pressure transducers were deployed to record the stage at nine different locations along the reach and to document the floods of May 20 and 29, 2017, at the South Platte River at Fort Morgan streamgage.

The hydraulic model was then used to compute 16 watersurface profiles for flood stages at 1-foot (ft; 0.3-meter [m]) intervals referenced to the streamgage datum and ranging from $12 \mathrm{ft}(3.66 \mathrm{~m})$ or below bankfull to $27 \mathrm{ft}(8.23 \mathrm{~m})$, which is $1 \mathrm{ft}$ $(0.3 \mathrm{~m})$ greater than the highest recorded water level $(25.73 \mathrm{ft}$ [7.84 m] on September 15, 2013) at the South Platte River at Fort Morgan streamgage during its period of record; the 2013 flood exceeds the major flood stage of $21.5 \mathrm{ft}(6.55 \mathrm{~m})$ by more than $4 \mathrm{ft}(1.2 \mathrm{~m})$, as defined by the National Weather Service.

The simulated water-surface profiles were then combined with a geographic information system digital elevation model (derived from light detection and ranging data having a $0.37-\mathrm{ft}$ [0.11-m] vertical accuracy and 3.28-ft [1.00-m] horizontal resolution) to delineate the area flooded for stages ranging from 12 to $27 \mathrm{ft}$ (3.66 to $8.23 \mathrm{~m})$.

These flood-inundation maps, in conjunction with the realtime stage data from the USGS streamgage on the South Platte River at Fort Morgan, are intended to help guide the general

\footnotetext{
${ }^{1}$ U.S. Geological Survey.
}

${ }^{2}$ Colorado Water Conservation Board. public in taking individual safety precautions and provide emergency management personnel with a tool to efficiently manage emergency flood operations and post flood recovery efforts.

\section{Introduction}

The South Platte River at Fort Morgan, Colorado, has experienced several floods with major flooding in 1921, 1935, 1965 (Follansbee and Sawyer, 1948; Matthai, 1969), and most recently during the September 2013 flood. A stage of 25.73 feet (ft; 7.84 meters [m]) and a discharge of 60,000 cubic feet per second $\left(\mathrm{ft}^{3} / \mathrm{s} ; 1,700\right.$ cubic meters per second $\left.\left[\mathrm{m}^{3} / \mathrm{s}\right]\right)$ were recorded for the South Platte River on September 15, 2013 (Kimbrough and Holmes, 2015); this flood stage is approximately $4 \mathrm{ft}(1.2 \mathrm{~m})$ greater than the major flood stage of $21.50 \mathrm{ft}$ (6.55 m; National Weather Service [NWS], 2018a). In 2017, the U.S. Geological Survey (USGS), in cooperation with the Colorado Water Conservation Board (CWCB), studied floods in the historic record to produce a library of floodinundation maps for the South Platte River at Fort Morgan.

Prior to this study, emergency responders relied on several online information sources to make decisions on how to best alert the public and mitigate flood damages. These sources of information include the USGS National Water Information System (NWIS) and the NWS Advanced Hydrologic Prediction Service (AHPS; https://water.weather.gov/ahps/about/about.php). Information from the USGS streamgage on the South Platte River at Fort Morgan (streamgage number 06759500; "Fort Morgan streamgage" for the purposes of this report) includes historical (from 1944 to 1958 and from 2002 to the present [2018]) water levels (stages) and discharges, including annual peak streamflows, is available through the NWIS web interface (USGS, 2018a). The NWS (2018a) displays the USGS stage data and issues flood forecasts for the Fort Morgan streamgage during times of high-stage streamflows.

Although the current stage at a USGS streamgage is particularly useful for residents in the immediate vicinity of a streamgage, it is of limited use to residents upstream or downstream because the out-of-bank topography, channel bathymetry, and water-surface elevations are not constant along the entire stream reach. Knowledge of a water level at a 
streamgage is difficult to translate into depth and areal extent of flooding at points distant from the streamgage. One way to address these informational gaps is to produce a library of flood-inundation maps that are referenced to the stages recorded at the streamgage. By referring to the appropriate flood-inundation map, emergency responders can discern the severity of flooding (depth of water and areal extent), identify roads that are or may be expected to soon be flooded, and make plans for notification or evacuation of residents in harm's way for a prescribed distance upstream and downstream from the streamgage (USGS, 2018b). In addition, the capability to visualize the potential extent of flooding has been shown to motivate residents to take precautions and heed warnings that might previously have been disregarded.

\section{Purpose and Scope}

This report describes the development of a series of estimated flood-inundation maps for the Fort Morgan streamgage and identifies where the flood-inundation maps can be found and ancillary data (geographic information system [GIS] flood polygons and depth grids) can be downloaded. The 16 floodinundation maps developed from this study cover a 4.5-mile (mi; 7.2-kilometer [km]) long reach of the South Platte River from Morgan County Road 16 to Morgan County Road 20.5 (fig. 1). The flood-inundation maps were produced for flood levels referenced to the stage recorded at the Fort Morgan streamgage (table 1), which is on the Colorado State Highway 52 and Morgan County Road 18.5 bridge.

The flood-inundation maps cover a range in stage from 12 to $27 \mathrm{ft}$ ( 3.66 to $8.23 \mathrm{~m}$ ) relative to the streamgage datum. The $15-\mathrm{ft}(4.57-\mathrm{m})$ stage is approximately bankfull and is defined by the NWS $(2018 \mathrm{a}, \mathrm{b})$ as the "action stage" or that stage which, when reached by a rising stream, requires the NWS or a partner to take some type of mitigation action in preparation for possible significant hydrologic activity. The $27-\mathrm{ft}(8.23-\mathrm{m})$ stage is $1 \mathrm{ft}(0.3 \mathrm{~m})$ greater than the highest recorded water level (25.73 ft [7.84 m] on September 15, 2013) at the streamgage during its period of record and the 2013 flood exceeds the "major flood stage" (NWS, 2018b) of $21.5 \mathrm{ft}(6.55 \mathrm{~m})$ by more than $4 \mathrm{ft}(1.2 \mathrm{~m})$.

\section{Study Area Description}

The South Platte River originates in central Colorado in the Rocky Mountains and flows in a northeasterly direction from the Rocky Mountains through Denver, then onto the High Plains and through Morgan County and Fort Morgan until it exits Colorado in the extreme northeastern corner (fig. 1). The basin terrain is characterized by steep mountains in the upstream part of the basin and gently rolling hills in the downstream part of the basin. The drainage area at the Fort Morgan streamgage is 14,648 square miles ( $\mathrm{mi}^{2}$; USGS, 2018c). The streamgage is in the middle of the study area, and the drainage area at the upstream end of the study area at
Morgan County Road 16 is $14,600 \mathrm{mi}^{2}$ (99.7 percent of the streamgage drainage area because the upstream end of the study area drains less area than the streamgage drainage area). No major tributaries enter the South Platte River in the study area. The drainage area at the downstream end of the study area at Morgan County Road 20.5 is $14,800 \mathrm{mi}^{2}$ (101.0 percent of the streamgage drainage area because the downstream end of the study area drains more area than the streamgage drainage area; USGS, 2018c).

The study area was chosen because of its proximity to Fort Morgan, consistency in drainage area through the study area, and risk of flooding. The study area is approximately $4.5 \mathrm{mi}(7.2 \mathrm{~km})$ long; the elevations at the upstream and downstream ends of the study area are 4,280 $\mathrm{ft}(1,304 \mathrm{~m})$ and $4,241 \mathrm{ft}(1,293 \mathrm{~m})$, respectively, which results in an average channel slope of 0.0016 foot per foot (ft/ft) or 8.7 feet per mile, and the average top-of-bank channel width is approximately $550 \mathrm{ft}(167 \mathrm{~m})$. Most of the land contiguous on the right bank or southern side of the study area is classified as woody wetlands or low-intensity development; most of the land on the left bank or northern side of the study area is classified as grasslands or cultivated crops (Homer and others, 2015). There is rapid population growth and development in the South Platte River Basin, in particular, the Denver metropolitan area, which stretches north to the city of Fort Collins. The Denver metropolitan area within the South Platte River Basin has had a population increase of more than 13 percent from 3,418,663 to 3,887,542 between 2010 and 2017 (U.S. Census Bureau, 2018). The main channel of the South Platte River within the study area has one bridge at State Highway 52 and one low-head dam leading to two irrigation canals, which as of April 2017, is maintained and operated by the Deuel and Synder Improvement Company and the Upper Platte and Beaver Canal Company. A levee exists along the right bank from the State Highway 52 bridge extending downstream 2,000 ft (610 m) to protect Riverside Park in Fort Morgan (fig. 1), but the levee is not included in the National Levee Database (U.S. Army Corps of Engineers [USACE], 2018). The berms on the streamward side of the Deuel and Synder Improvement Company canal and the Upper Platte and Beaver Canal Company canal were also simulated in the model as a levee to confine streamflow to the channel.

\section{Previous Studies}

The Federal Emergency Management Agency (FEMA) flood insurance study in effect currently [2018] for the South Platte River in Morgan County, available on the FEMA Flood Map Service Center website (FEMA, 2018b), was published on April 4, 2018, (FEMA, 2018a). A previous flood insurance study was published in 1989 on the South Platte River for unincorporated areas of Morgan County, and another, in 1986 on the South Platte River for the city of Fort Morgan (FEMA, 2018a). Following the September 2013 flood, the CWCB has taken steps toward long-term planning and resiliency efforts for flooding. The Colorado Hazard Mapping Program 


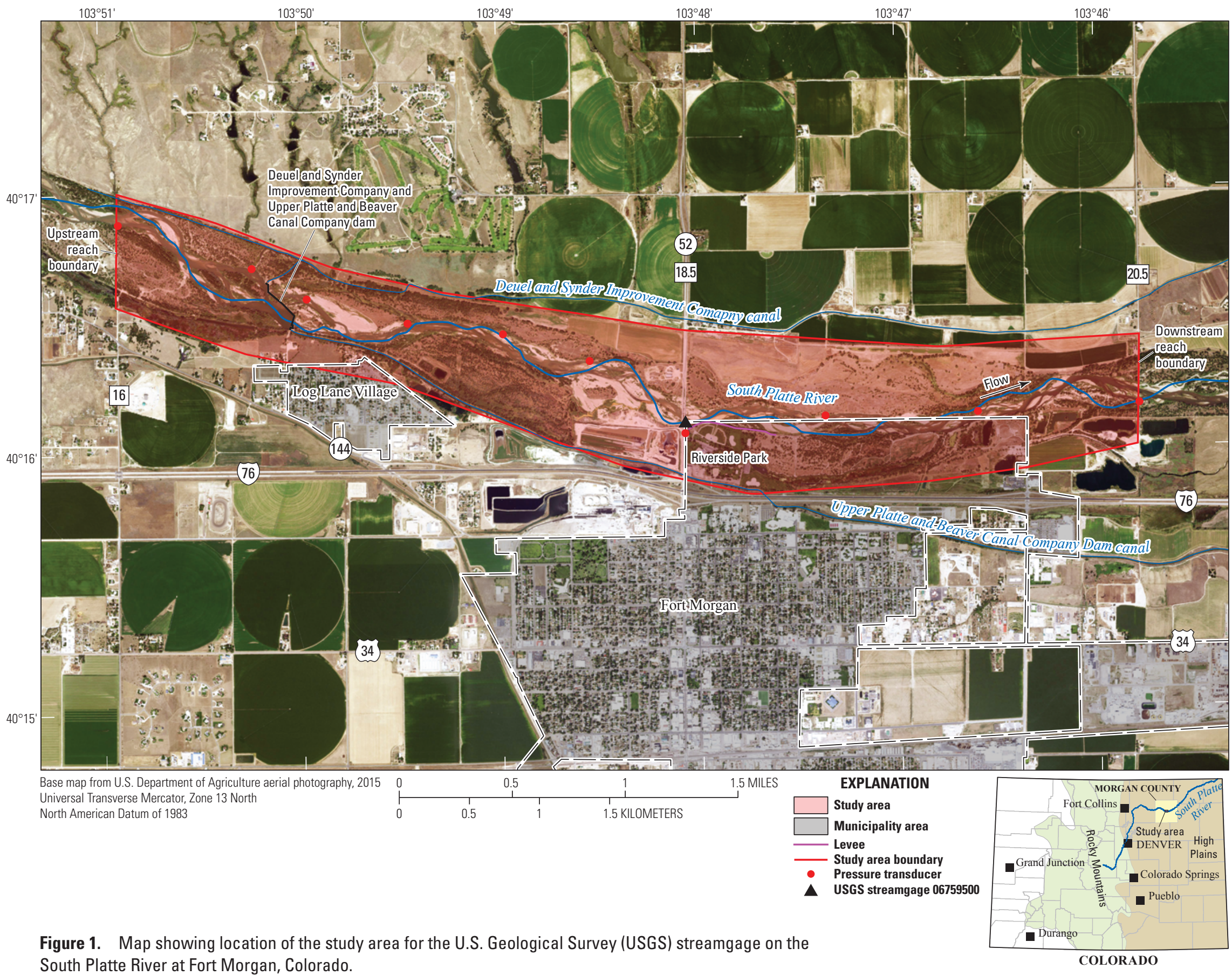


Table 1. Information about the U.S. Geological Survey streamgage on the South Platte River at Fort Morgan, Colorado.

[Location of streamgage shown on figure 1. $\mathrm{mi}^{2}$, square mile; ft, foot; NAVD 88, North American Vertical Datum of $1988 ; \mathrm{ft}^{3} / \mathrm{s}$, cubic foot per second]

\begin{tabular}{lc}
\hline \multicolumn{1}{c}{ Streamgage name } & South Platte River at Fort Morgan, CO \\
\hline Streamgage number & 06759500 \\
Drainage area $\left(\mathrm{mi}^{2}\right)$ & 14,648 \\
Latitude & $40^{\circ} 16^{\prime} 6.25^{\prime \prime}$ \\
Longitude & $-103^{\circ} 48^{\prime} 4.29^{\prime \prime}$ \\
Period of peak-flow record (water years $\left.{ }^{1}\right)$ & 25.73 \\
Maximum recorded stage (ft) & $4,271.82$ \\
Elevation at maximum recorded stage (ft, NAVD 88) & September 15,2013 \\
Date of maximum recorded stage & 60,000 \\
Maximum discharge (ft ${ }^{3 /}$ s) & September 15,2013 \\
Date of maximum discharge & and 2002 to present \\
\hline
\end{tabular}

${ }^{1}$ Water year is the 12-month period from October 1 of one year through September 30 of the following year and is designated by the calendar year in which it ends.

(CHAMP) is preparing updated hazard information for streams like the South Platte River. The updated information from this program is intended to be used to update the flood insurance study (CWCB, 2018). Following the September 2013 flood, the CWCB published a series of annual exceedance probability discharges for various locations in the South Platte River Basin, including the Fort Morgan streamgage (Carrier, 2016). The annual exceedance probability discharges were determined using streamflow data through water year 2015 and include the flood data from the September 2013 flood. Carrier (2016) presents estimates of the peak discharges with 10-, 2-, 1-, and 0.2-percent annual exceedance probabilities (table 2) for the Fort Morgan streamgage.

\section{Creation of Flood-Inundation-Map Library}

The USGS standardized the procedures for creating flood-inundation maps for flood-prone communities (USGS, $2018 \mathrm{~b})$ so that the process followed for creating flood-inundation maps and products produced are similar regardless of which USGS office is responsible for the work. Tasks specific to the development of the flood-inundation maps for the South Platte River at Fort Morgan were as follows:

- compile flood data from Fort Morgan streamgage (table 1),

- collect additional stage data by deploying pressure transducers throughout the study area,

- collect and compile topographic and bathymetric data for selected cross sections and geometric data for structures and bridges along the study area,
Table 2. Peak discharges from for the U.S. Geological Survey streamgage on the South Platte River at Fort Morgan, Colorado, (streamgage number 06759500) through water year 2015.

[Discharge data are from Carrier (2016) and are estimated. $\mathrm{ft}^{3} / \mathrm{s}$, cubic foot per second]

\begin{tabular}{cc}
\hline \multicolumn{2}{c}{$\begin{array}{c}\text { Estimated discharges }\left(\mathbf{f t}^{3} / \mathbf{s}\right) \text { for indicated annual exceedance } \\
\text { probabilities (percent) }\end{array}$} \\
\hline $\begin{array}{c}\text { Annual exceedance probability } \\
\text { (percent) }\end{array}$ & $\begin{array}{c}\text { Discharge } \\
\left(\mathbf{f t}^{3} / \mathbf{s}\right)\end{array}$ \\
\hline 10 & 20,300 \\
2 & 55,500 \\
1 & 80,700 \\
0.2 & 178,000 \\
\hline
\end{tabular}

- estimate energy-loss factors (roughness coefficients) in the stream channel and flood plain and determination of steady-flow data,

- compute water-surface profiles using the USACE Hydrologic Engineering Center River Analysis System (HEC-RAS) computer program (USACE, 2016a)

- produce estimated flood-inundation maps at various stages using the USACE Hydrologic Engineering Center GeoRiver Analysis System (HEC-GeoRAS) computer program (USACE, 2011) and Esri, Inc. ArcGIS (Esri, Inc., 2018), and

- prepare flood-inundation maps, both as shapefile polygons that depict the areal extent of flood inundation and as depth grids that provide the depth of floodwaters, for display on a USGS flood-inundation mapping application (USGS, 2018b). 


\section{Computation of Water-Surface Profiles}

The water-surface profiles used to produce the 16 floodinundation maps in this study were computed using HEC-RAS, version 5.0.3 (USACE, 2016a,b). The HEC-RAS model is applicable to a wide range of scenarios, including large networks of regulated or natural streams or rivers to constructed channels (USACE, 2016b), and is a one-dimensional, stepbackwater model for simulation of water-surface profiles with steady-state (gradually varied) or unsteady-state streamflow computation options (USACE, 2016a).

\section{Hydrologic Data}

The study area includes one USGS streamgage (fig. 1; table 1) that has been in operation since December 2001 and from 1944 to 1958. Stage is measured every 15 minutes, transmitted hourly by satellite telemetry in the streamgage, and made available through the NWIS web interface (https://doi.org/10.5066/F7P55KJN). Stage data from this streamgage are referenced to the streamgage datum but can be converted to water-surface elevations referenced to the North American Vertical Datum of 1988 (NAVD 88) by adding 4,246.09 ft (1,294.21 m). Continuous records of streamflow are computed from a stage-discharge relation, which has been developed for the streamgage (Rantz and others, 1982); the continuous records are available through the NWIS web interface (https://doi.org/10.5066/F7P55KJN).

The streamflows used in the model simulations (table 3) corresponded with the target stages of 12 to $27 \mathrm{ft}$ (3.66 to $8.23 \mathrm{~m}$ ) relative to the streamgage datum. This stage-discharge relation was extended as a part of this study using the calibrated model to determine the discharge at $27 \mathrm{ft}(8.23 \mathrm{~m})$ then extending the stage-discharge relation to this point.

In the past 15 years, there are few high-flow measurements due to the relatively short period of record, upstream regulation, and arid hydrology of the drainage basin. Thus, instead of calibrating to the stage-discharge relation, the highest streamflows at the Fort Morgan streamgage from the past several years were used for model calibration. To calibrate the HEC-RAS model that was developed for this study, 10 Onset Computer Corporation HOBO U20-04 pressure transducers were deployed in the study area from April to October 2017; nine of the pressure transducers were deployed to record the stage at nine different locations along the reach and to document the floods of May 20 and 29, 2017 at the South Platte River at Fort Morgan streamgage (fig. 1; Kohn, 2017), and the tenth pressure transducer was deployed to measure the atmospheric pressure in the study area, which is needed to determine the stage for the other nine pressure transducers (Onset Computer Corporation, 2018). The floods of September 15, 2013, June 15, 2015, May 20, 2017, and May 29, 2017, were used to calibrate and validate the HEC-RAS model (Kohn, 2018). The September 15, 2013, and May 20, 2017 floods were used to calibrate the model, and the June 15, 2015, and May 29, 2017, floods were used to independently validate the model. The stages measured by the nine pressure transducers during the associated peak discharge at the Fort Morgan streamgage for the floods of May 20 and 29, 2017, are listed in table 3. Because no major tributaries contribute to the South Platte River within the $4.5-\mathrm{mi}(7.2-\mathrm{km})$ long study area, the streamgage-derived discharges were not adjusted for tributary inflows but were held constant throughout the study area for a given profile.

\section{Topographic and Bathymetric Data}

All topographic data used in this study are referenced vertically to the NAVD 88 and horizontally to the North American Datum of 1983 (NAD 83). Cross-section elevation data were obtained from light detection and ranging (lidar) and real-time kinematic Global Navigation Satellite Systems (RTK-GNSS) data. Because lidar data cannot provide ground elevations below a stream's water surface, channel cross sections were surveyed by USGS field crews using RTK-GNSS data from February 15 through April 18, 2017 (Kohn, 2017). Cross-sectional depths were measured by wading at 54 cross-section locations. An RTK-GNSS survey was used to derive horizontal locations and the elevation of the water surface at each surveyed cross section. Elevations determined by an RTK-GNSS at three existing USGS benchmark locations were verified to be within $0.13 \mathrm{ft}(0.040 \mathrm{~m})$, an error range that falls within the accuracy of the lidar data. The flood plains were derived from a digital elevation model (DEM) that was derived from lidar data that were collected during October 2013 by Photo Science (USGS, 2018d). Postprocessing of these data were completed by Photo Science on July 1, 2014. The original lidar data have a horizontal resolution of $3.28 \mathrm{ft}(1.00 \mathrm{~m})$ and vertical accuracy of $0.37 \mathrm{ft}$ $(0.11 \mathrm{~m})$ at a 95 -percent confidence level for the "open terrain" land-cover category (root mean squared error of $0.19 \mathrm{ft}[0.057 \mathrm{~m}])$. Based on these criteria, the lidar data support production of 1-ft (0.3-m) contours (Dewberry, 2012). HEC-GeoRAS (USACE, 2011) has a set of procedures, tools, and utilities for processing geospatial data in Esri, Inc. ArcGIS (Esri, Inc., 2018) and was used to extract elevation data from the DEM (USGS, 2018d) for 54 cross sections and input to the HEC-RAS model. DEM-generated cross sections were made to coincide with the locations of the withinchannel field-surveyed cross sections. Within-channel data were directly merged with the DEM data (USGS, 2018d). An additional 10 cross sections were provided in HEC-RAS by AECOM as part of the CWCB's CHAMP (CWCB, 2018).

\section{Hydraulic Structures}

Two hydraulic structures (fig. 1), consisting of one road crossing (Colorado State Highway 52) and a low-head dam (the Deuel and Synder Improvement Company and the Upper Platte and Beaver Canal Company Dam), have the potential to affect water-surface elevations during floods along the South Platte River. Bridge and low-head dam 
Table 3. Calibration of model to target water-surface elevations at the U.S. Geological Survey streamgage on the South Platte River at Fort Morgan, Colorado (streamgage number 06759500), and nine pressure transducer locations for four floods.

[Locations shown on figure 3. Discharge from streamgage number 06759500 (U.S. Geological Survey, 2018a). $\mathrm{ft}$, foot; $\mathrm{ft}^{3} / \mathrm{s}$, cubic foot per second; NAVD 88, North American Vertical Datum of 1988; NA, not applicable]

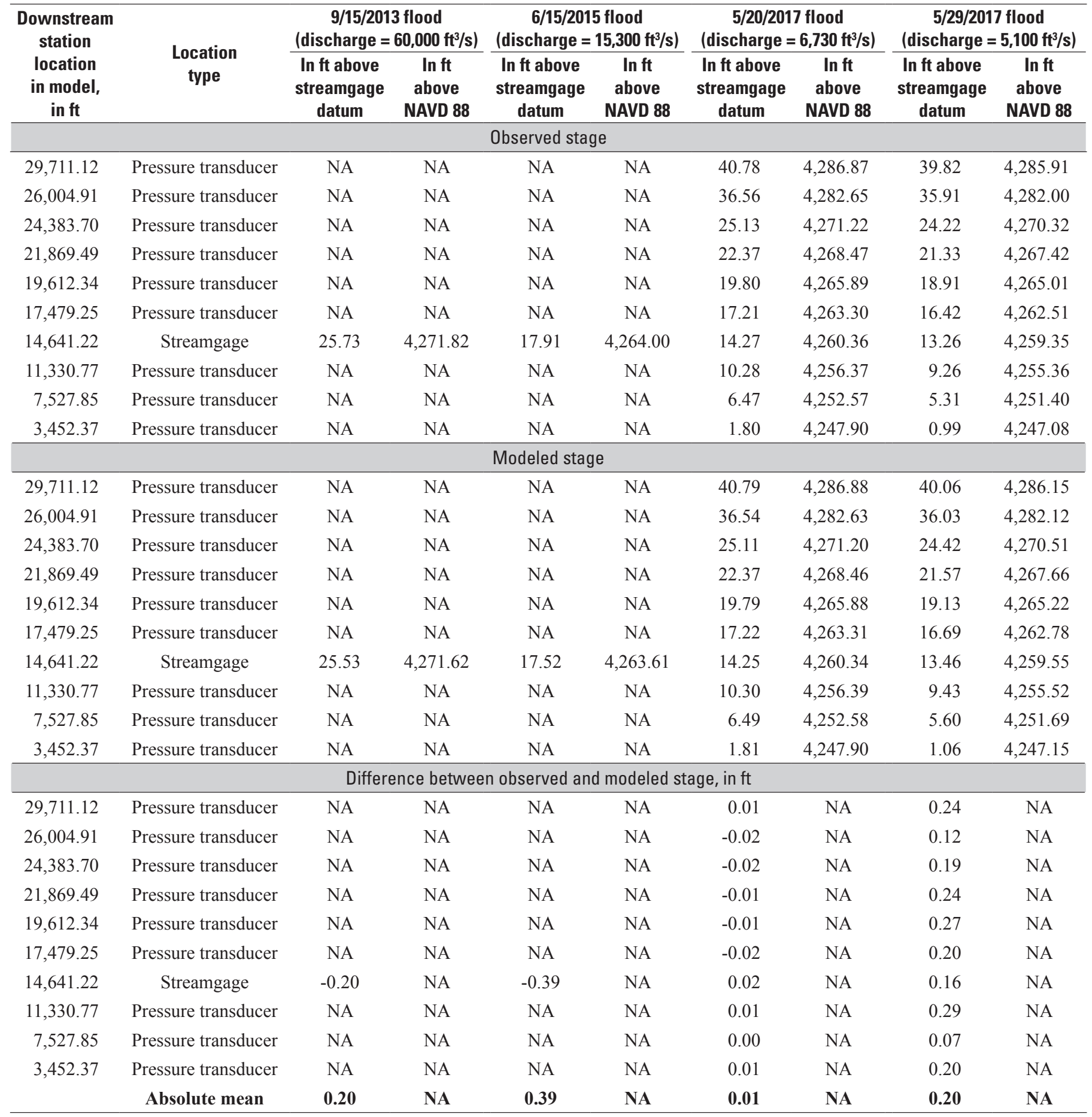


geometry data were provided in HEC-RAS by AECOM as part of the CWCB's CHAMP (CWCB, 2018). To calibrate to the large flood discharges at the Fort Morgan streamgage, which was located on the downstream side of the bridge at Colorado State Highway 52, a contraction coefficient of 1.0 was used at this location, which is not unreasonable for the large contraction that occurs at the bridge at high streamflows.

The low-head dam can divert as much as $83 \mathrm{ft}^{3} / \mathrm{s}$ $\left(2.35 \mathrm{~m}^{3} / \mathrm{s}\right)$ to the canal owned by the Deuel and Synder Improvement Company (Joe Baumberger, oral commun., April 6, 2017) and as much as $234 \mathrm{ft}^{3} / \mathrm{s}\left(6.63 \mathrm{~m}^{3} / \mathrm{s}\right)$ to the canal owned by the Upper Platte and Beaver Canal Company (Bart Ginther, oral commun., April 6, 2017). These diversions were deemed inconsequential when compared with the magnitude of the flood discharges, and no diversions were included in the HEC-RAS simulations. A levee with an elevation of about $4,270 \mathrm{ft}(1,301 \mathrm{~m})$ is in place along the right bank from the State Highway 52 bridge extending downstream 2,000 ft $(610 \mathrm{~m})$ to protect Riverside Park in Fort Morgan (fig. 1), but the levee is not included in the National Levee Database (USACE, 2018). Because this levee was overtopped during the September 2013 flood, the levee was simulated as a levee with effective streamflow outside the levee in the HEC-RAS model. The streamflows corresponding to the 24 - to $27-\mathrm{ft}(7.32-$ to $8.23-\mathrm{m})$ target stages were the only streamflows large enough to overtop the levee because the water-surface elevations exceeded the levee elevation $(4,270 \mathrm{ft}[1,301 \mathrm{~m}])$ at those streamflows (table 4).

\section{Energy-Loss Factors}

Hydraulic analyses require the estimation of energy losses that result from frictional resistance exerted by a channel on streamflow. These energy losses are quantified by the Manning's roughness coefficient ( $n$ value). Initial (precalibration) $n$ values were selected based on field observations and photographs during the RTK-GNSS survey and high-resolution aerial photographs (U.S. Department of Agriculture, Farm Service Agency, 2015) using the Cowan method (Cowan, 1956). The South Platte River in the study area comprises a wide, sand bed channel that contains frequent sand bars, which can be vegetated; otherwise, the channel is typically free of vegetation (fig. 2). The channel is braided at base flow; however, during floods, the channel comprises one main channel with little meandering due to the high channel slopes. Dead cottonwood trees and other large dead woody debris are sporadically lodged in the channel and create occasional streamflow obstructions. The banks along the channel can be moderately steep and irregular and typically comprised of sand. There is vegetation of widely varying sizes along the banks, including grasses, willows, and cottonwood trees. The vegetation density changes dramatically through the stream reach, creating large variation in bank roughness. The flood plains consist of mixed land use but are dominated by pasture and grasslands. Small parts of the flood plain contain
Table 4. Flood stages and corresponding discharges used to generate flood-inundation maps for the U.S. Geological Survey streamgage on the South Platte River at Fort Morgan, Colorado (streamgage number 06759500).

[ft, foot; NAVD 88, North American Vertical Datum of 1988; $\mathrm{ft}^{3} / \mathrm{s}$, cubic foot per second]

\begin{tabular}{ccc}
\hline $\begin{array}{c}\text { Stage } \\
\text { (ft above } \\
\text { streamgage datum) }\end{array}$ & $\begin{array}{c}\text { Stage } \\
\text { (ft above } \\
\text { NAVD 88) }\end{array}$ & $\begin{array}{c}\text { Discharge } \\
\text { (ft } \mathbf{s}^{\mathbf{s})}\end{array}$ \\
\hline 12 & 4258.09 & 2,820 \\
13 & 4259.09 & 4,310 \\
14 & 4260.09 & 6,190 \\
15 & 4261.09 & 8,370 \\
16 & 4262.09 & 10,900 \\
17 & 4263.09 & 13,700 \\
18 & 4264.09 & 16,900 \\
19 & 4265.09 & 20,400 \\
20 & 4266.09 & 24,300 \\
21 & 4267.09 & 28,700 \\
22 & 4268.09 & 33,800 \\
23 & 4269.09 & 40,000 \\
24 & 4270.09 & 47,000 \\
25 & 4271.09 & 55,200 \\
26 & 4272.09 & 64,600 \\
27 & 4273.09 & 99,400 \\
\hline
\end{tabular}

cottonwood trees, sand quarries, or low-density development, but most of these areas are on elevated ground, a distance from the channel. These physical characteristics of the channel, banks, and adjacent flood plains can cause a large variation in channel roughness. As a result, each cross section was subdivided into five parts for assignment of $n$ values: the channel, the left and right banks, and the left and right flood plains.

As part of the calibration process, the initial $n$ values were varied by streamflow and adjusted until the differences between simulated and observed water-surface elevations at the streamgage and the nine pressure transducers were minimized. The final $n$ values ranged from 0.018 to 0.065 for the main channel, 0.080 to 0.213 for the left and right bank areas, and 0.072 to 0.276 for the left and right flood plains simulated in this analysis (Kohn, 2018).

\section{Hydraulic Model}

The HEC-RAS simulations for this study were carried out using the steady-state streamflow computation option. Steady-state streamflow data consisted of streamflow regime, boundary conditions, and peak streamflows that produced water-surface elevations at the streamgage cross section 


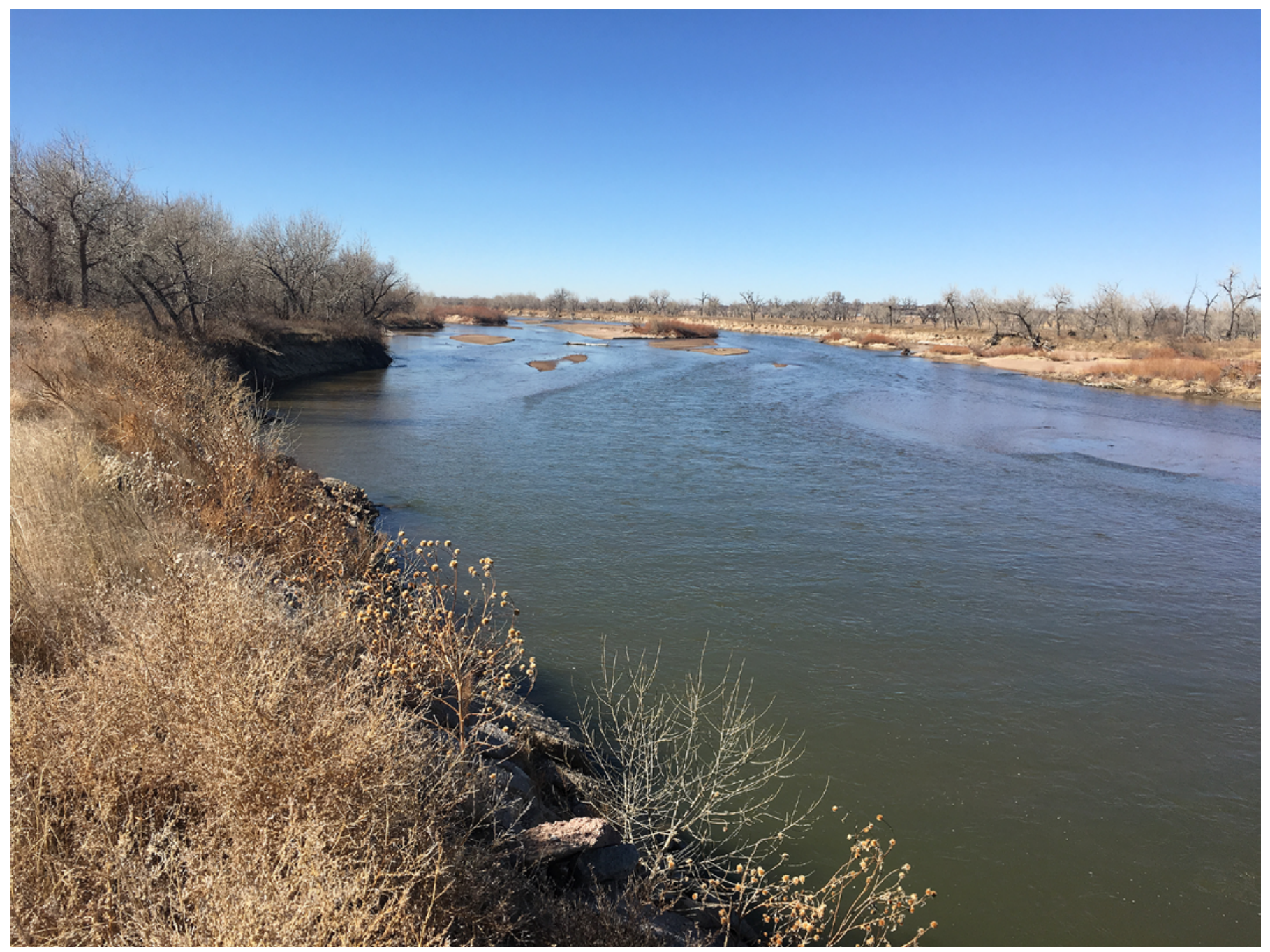

Figure 2. Photograph of the South Platte River at Fort Morgan, Colorado study area; looking upstream at the channel and left and right banks; by Michael S. Kohn, U.S. Geological Survey.

that matched water-surface elevations of the target stages (target water-surface elevations). These target water-surface elevations coincided with $1-\mathrm{ft}(0.3-\mathrm{m})$ increments of stage, referenced to the local streamgage datum. A subcritical (tranquil) streamflow regime was assumed for the simulations. A normal depth downstream boundary condition was used based on an estimated average water-surface slope of $0.0011 \mathrm{ft} / \mathrm{ft}$ from the May 20, 2017, flood pressure transducer data at the two downstream-most pressure transducers, which were located at river stations 7,527.85 ft $(2,294.49 \mathrm{~m})$ and 3,452.37 ft $(1,052.28 \mathrm{~m})$ in the HEC-RAS model (fig. 3; table 3). The peak streamflows that were used in the model are discussed in the "Hydrologic Data" section.

The HEC-RAS model was calibrated and validated to the stage data for the associated peak discharges at the Fort Morgan streamgage during September 15, 2013, and June 15, 2015, floods and the stage data at the nine pressure transducers deployed along the reach in 2017 that documented the May 20 and 29, 2017, floods at the Fort Morgan streamgage (table 3; Kohn, 2018). The September 15, 2013, and May 20, 2017, floods were used to calibrate the model, and the June 15, 2015, and May 29, 2017, floods were used to independently validate the model. Measured stages at the nine pressure transducers during the associated peak discharge at the Fort Morgan streamgage for the floods of May 20 and 29, 2017, were available.

The model was calibrated by adjusting Manning's $n$ values until the results of the hydraulic computations closely agreed with the observed water-surface elevations for given streamflows. Differences between observed and simulated water-surface elevations for the four simulated streamflows at the USGS streamgage and nine pressure transducer stages were equal to or less than $0.39 \mathrm{ft}(0.12 \mathrm{~m}$; table 3). The results demonstrate that the model is capable of simulating accurate water levels over a wide range of streamflows in the basin. 


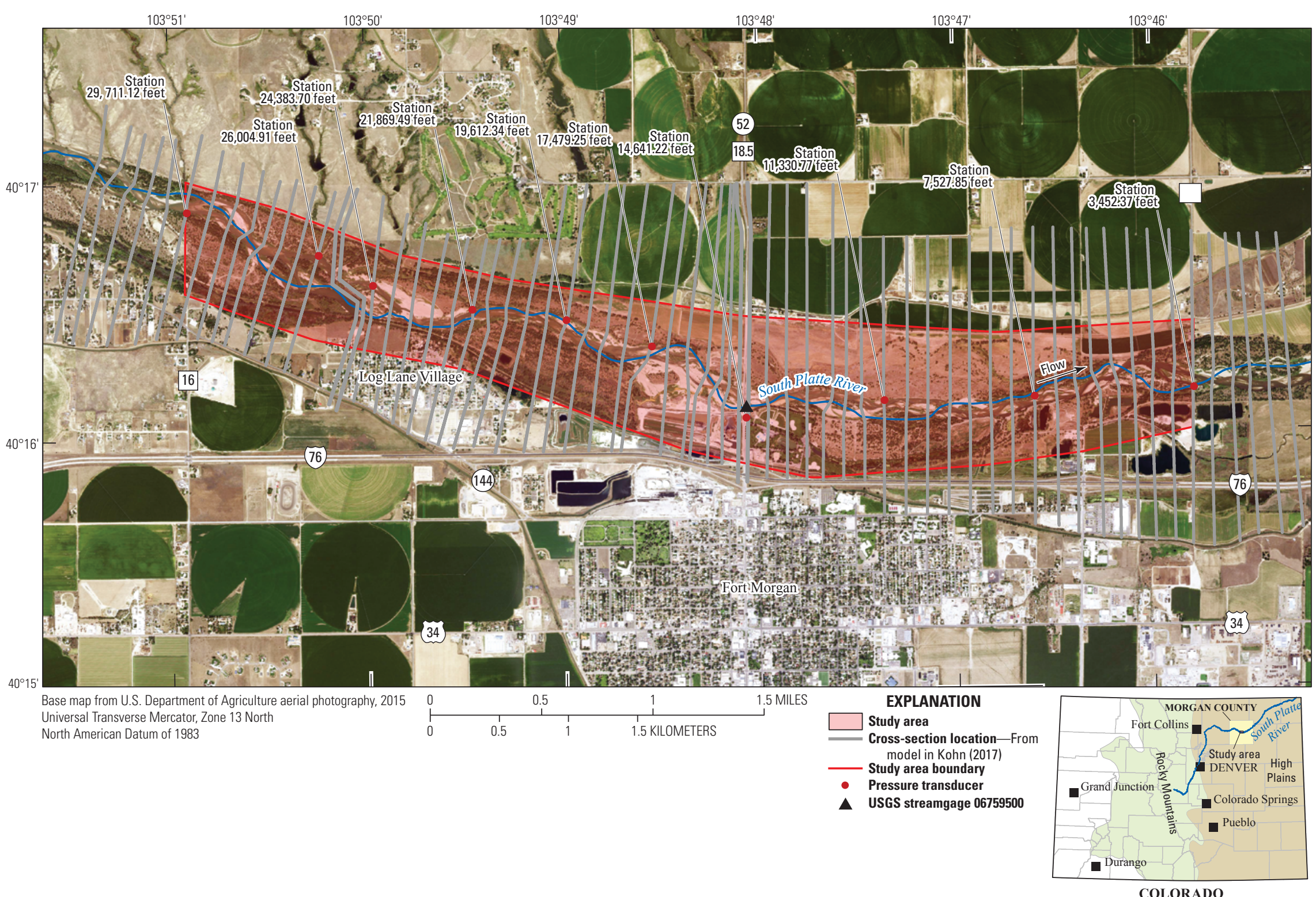

COLORADO

Figure 3. Map showing the study area for the U.S. Geological Survey (USGS) streamgage on the South Platte River at Fort Morgan, Colorado (streamgage number 06759500), including pressure transducers and cross sections used to simulate flood stage. 


\section{Development of Water-Surface Profiles}

The calibrated hydraulic model was used to generate water-surface profiles for a total of 16 stages (table 4 ) at 1-ft $(0.3-\mathrm{m})$ intervals between $12 \mathrm{ft}(3.66 \mathrm{~m})$ or below bankfull to $27 \mathrm{ft}(8.23 \mathrm{~m})$, which is more than $1 \mathrm{ft}(0.3 \mathrm{~m})$ higher than the highest recorded water level $(25.73 \mathrm{ft}[7.84 \mathrm{~m}]$ on September 15, 2013) at the Fort Morgan streamgage during its period of record; the 2013 flood exceeds the major flood stage, as defined by the NWS (2018a), of $21.5 \mathrm{ft}(6.55 \mathrm{~m})$ by more than $4 \mathrm{ft}(1.2 \mathrm{~m})$. These stages correspond to elevations of 4,258.09 ft (1,297.87 m) to 4,273.09 ft (1,302.44 m), NAVD 88, respectively (table 4).

\section{Development of Flood-Inundation Maps}

Flood-inundation maps were created for the Fort Morgan streamgage, which has been designated as an NWS river probability and forecast point (NWS, 2018a). The floodinundation maps were created in Esri, Inc. ArcGIS (Esri, Inc., 2018 ) by combining 16 water-surface profiles and DEM data. The DEM data were derived from the lidar data described in the "Topographic and Bathymetric Data" section and have an estimated vertical accuracy of $0.37 \mathrm{ft}(0.11 \mathrm{~m} ; \pm 0.185 \mathrm{ft}$ $[0.056 \mathrm{~m}])$. Estimated flood-inundation boundaries for each simulated profile were developed using the RAS Mapper tool within the HEC-RAS version 5.0.3 software (USACE, 2016a,b), which processes HEC-RAS simulation results. Shapefile polygons and depth grids of the inundated areas for each of the 16 profiles were modified, as required, in the ArcMap application of Esri, Inc. ArcGIS (Esri, Inc., 2018) to ensure a hydraulically reasonable transition of the flood boundaries between modeled cross sections.

The HEC-RAS model utilizes ineffective streamflow areas in locations that could potentially be inundated during a flood but due to the topography or adjacent obstructions would not convey water during a flood. These areas are backwater areas where water ponds during a flood. The canals were designated as ineffective areas because the water in the canals is transported out of the channel for irrigation and will not be returned to the channel. Several ponds exist in the flood plains, and these areas were designated as ineffective streamflow areas because water in the ponds is stagnant and is not transported downstream. The cross section immediately upstream and the cross section immediately downstream of the bridge at Colorado State Highway 52 were designated ineffective streamflow areas in the parts of the cross sections that were adjacent to the highway embankment because the embankment prevents flow in those areas.

Any inundated areas that were detached from the main channel were examined to identify subsurface connections with the main river, such as through culverts under roadways. Where such connections existed, the mapped inundated areas were retained in their respective flood maps; otherwise, the erroneously delineated parts of the flood extent were deleted. In Riverside Park, which is adjacent to the levee, the flood-inundation maps were modified to allow backwater from downstream of the levee to pond behind the levee based on the water-surface elevation downstream of the levee even if the levee was not overtopped. The flood-inundation areas are overlaid on high-resolution, georeferenced aerial photographs of the study area. The bridge surface is displayed as not inundated because the bridge deck was never below the water-surface elevation. Estimates of water depth can be obtained from the depth-grid data that are included with the presentation of the floodinundation maps on the interactive USGS Flood Inundation Mapper application (https://wimcloud.usgs.gov/apps/FIM/ FloodInundationMapper.html) described in the "FloodInundation Map Delivery" section. The flood-inundation map corresponding to the highest simulated water-surface profile, a stage of $27 \mathrm{ft}(8.23 \mathrm{~m})$, is presented in figure 4 .

\section{Flood-Inundation Map Delivery}

The flood extent polygons, flood depths grids, and hydraulic model are available in Kohn (2018). The topographic data used in the model are available in Kohn (2017). The USGS Flood Inundation Mapping Program website (https://water.usgs.gov/osw/flood_inundation) provides USGS flood-inundation study information to the public. The website links to the Flood Inundation Mapper application that presents map libraries and provides detailed information on flood extents and depths for modeled sites. For the Fort Morgan streamgage, the mapping application enables the production of customized flood-inundation maps from the map library. The customized maps provide a link to the NWIS web interface entry for the Fort Morgan streamgage (USGS, 2018a), which presents the current stage and streamflow at the Fort Morgan streamgage.

The estimated flood-inundation maps are displayed in sufficient detail so that preparations for flooding and decisions for emergency response can be performed efficiently. Depending on the flood magnitude, roadways are shown as shaded (inundated and likely impassable) or not shaded (dry and passable) to facilitate emergency planning and use. A shaded building should not be interpreted to mean that the structure is completely submerged; rather, that bare-earth surfaces in the vicinity of the building are inundated. In these instances, the water depth (as indicated in the mapping application by holding the cursor over an inundated area) near the building would be an estimate of the water level inside the structure, unless flood-proofing measures had been implemented.

\section{Disclaimer for Flood-Inundation Maps}

The flood-inundation maps should not be used for navigation, regulatory, permitting, or other legal purposes. The USGS provides these flood-inundation maps "as-is" for a quick reference, emergency planning tool but assumes no legal liability or responsibility resulting from the use of this information. 


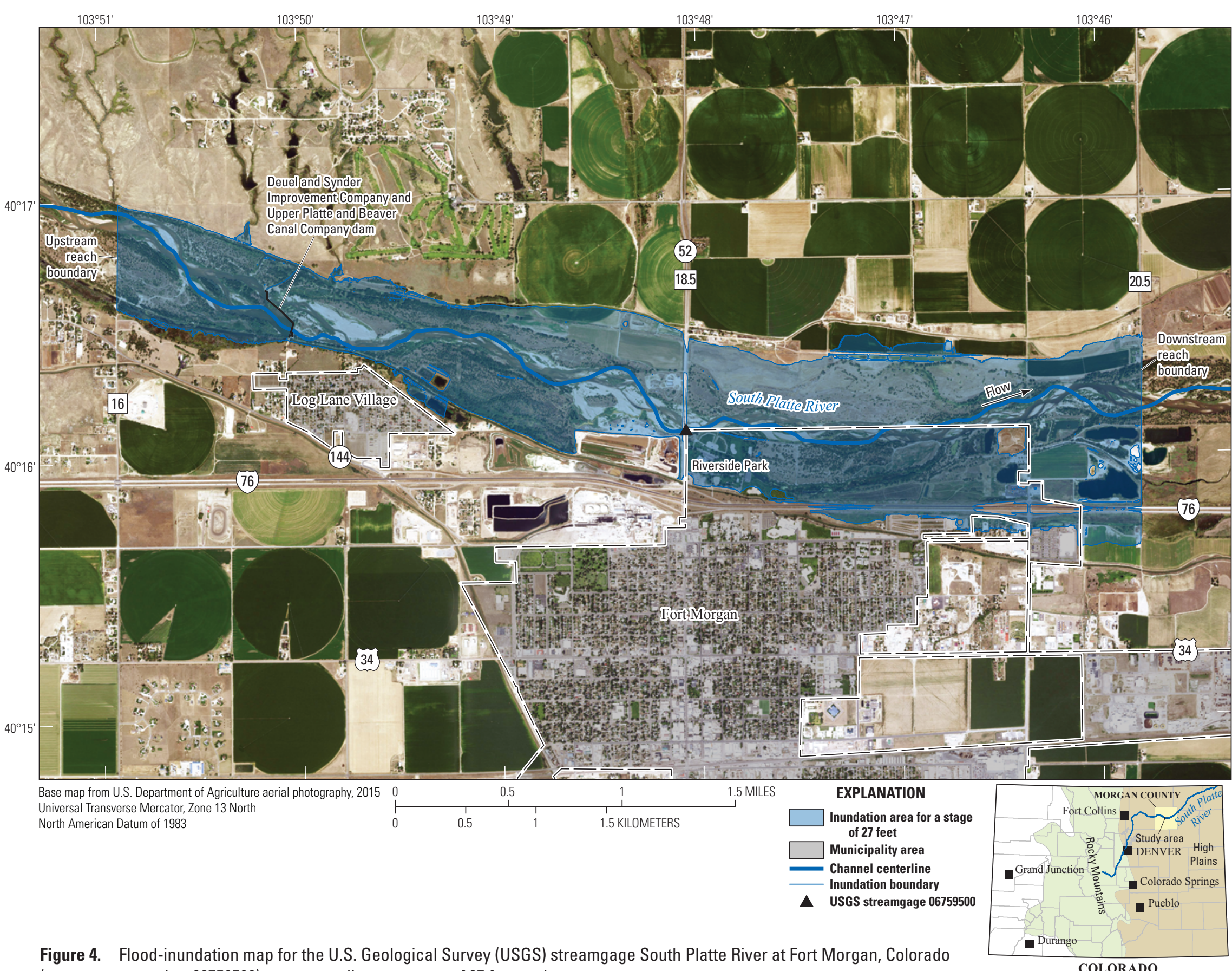




\section{Uncertainties and Limitations Regarding Use of Flood-Inundation Maps}

Although the flood-inundation maps represent the boundaries of inundated areas with a distinct line, some uncertainty is associated with these flood-inundation maps. The flood boundaries shown were estimated based on the stages and streamflows at selected USGS streamgage(s). Water-surface elevations along the stream reaches were estimated by steadystate hydraulic modeling, assuming unobstructed streamflow, and used streamflows and hydrologic conditions anticipated at the USGS streamgage(s). The hydraulic model reflects the land-cover characteristics and any bridge, dam, levee, or other hydraulic structures existing as of April 2017. Unique meteorological factors (timing and distribution of precipitation) may cause actual streamflows along the modeled reach to vary from those assumed during a flood, which may lead to deviations in the water-surface elevations and inundation boundaries shown. Additional areas may be flooded due to unanticipated conditions such as changes in the streambed elevation or roughness, backwater into major tributaries along a main-stem river, or backwater from localized debris or ice jams. The accuracy of the floodwater extent portrayed on these flood-inundation maps will vary with the accuracy of the DEM used to simulate the land surface.

If this series of flood-inundation maps will be used in conjunction with NWS river forecasts, the user should be aware of additional uncertainties that may be inherent or factored into NWS forecast procedures. The NWS uses forecast models to estimate the quantity and timing of water flowing through selected stream reaches in the United States. These forecast models (1) estimate the amount of runoff generated by precipitation and snowmelt, (2) simulate the movement of floodwater as it proceeds downstream, and (3) predict the streamflow and stage (and water-surface elevation) for the stream at a given location (AHPS forecast point) throughout the forecast period (every 6 hours and 3 to 5 days out in many locations). More information on AHPS forecasts is available at https://water.weather.gov/ahps/about/about.php.

In Riverside Park adjacent to the levee, the flood-inundation maps are developed with the assumption that the levee does not fail or breach until the stage in the river exceeds the levee elevation. However, areas behind the levee may become inundated due to backwater in the flood plain located downstream of the levee. The areas near the Deuel and Synder Improvement Company and the Upper Platte and Beaver Canal Company Dam may have a larger uncertainty depending on dam and adjacent irrigation ditch operations compared to the study area as a whole.

\section{Summary}

In 2017, the U.S. Geological Survey (USGS), in cooperation with the Colorado Water Conservation Board, studied floods in the historic record to produce a library of flood-inundation maps for the South Platte River at Fort Morgan, Colorado. A series of 16 digital flood-inundation maps were developed for the USGS streamgage on the South Platte River at Fort Morgan (streamgage number 06759500). The flood-inundation maps cover a reach about 4.5 miles (7.2 kilometers) long from Morgan County Road 16 to Morgan County Road 20.5. The flood-inundation maps were developed by using the U.S. Army Corps of Engineers Hydrologic Engineering Center River Analysis System and Hydrologic Engineering Center GeoRiver Analysis System programs to compute water-surface profiles and delineate estimated flood-inundation areas and depths of flooding for selected stages. The September 15, 2013, and May 20, 2017, floods were used to calibrate the model, and the June 15, 2015, and May 29, 2017, floods were used to independently validate the model. Nine pressure transducers were deployed to record the stage at nine different locations along the reach and to document the floods of May 20 and 29, 2017, at the South Platte River at Fort Morgan streamgage.

The model was used to compute 16 water-surface profiles for stages at 1-foot (ft; 0.3-meter [m]) intervals referenced to the streamgage datum and ranging from $12 \mathrm{ft}(3.66 \mathrm{~m})$ or below bankfull to $27 \mathrm{ft}(8.23 \mathrm{~m})$, which is more than $1 \mathrm{ft}(0.3 \mathrm{~m})$ higher than the highest recorded water level $(25.73 \mathrm{ft}$ [7.84 m] on September 15, 2013) at the Fort Morgan streamgage during its period of record; the 2013 flood exceeds the major flood stage, as defined by the National Weather Service, of $21.5 \mathrm{ft}(6.55 \mathrm{~m})$ by more than $4 \mathrm{ft}(1.2 \mathrm{~m})$. The simulated, water-surface profiles were then combined with a geographic information system digital elevation model derived from light detection and ranging data to delineate estimated flood-inundation areas as shapefile polygons and depth grids for each profile. These flood-inundation polygons were overlaid on high-resolution, georeferenced aerial photographs of the study area. These flood-inundation maps, in conjunction with the real-time stage data from the Fort Morgan streamgage, are intended to help guide the general public in taking individual safety precautions and provide emergency management personnel with a tool to efficiently manage emergency flood operations and post flood recovery efforts. 


\section{References Cited}

Carrier, W.J., 2016, South Platte River watershed; Phase 2 hydrologic evaluation: Colorado Department of Transportation and Colorado Water Conservation Board, $16 \mathrm{p}$., accessed May 4, 2018, at http://cwcbweblink.state.co.us/ weblink/0/doc/199243/Electronic.aspx?searchid=df5d90dccd42-4647-afe9-ed81 ceb208ad.

Colorado Water Conservation Board (CWCB), 2018, Colorado hazard mapping program: Colorado Water Conservation Board MAP portal, accessed April 18, 2018, at http://coloradohazardmapping.com/.

Cowan, W.L., 1956, Estimating hydraulic roughness coefficients: Agricultural Engineering, v. 37, no. 7, p. 473-475.

Dewberry, 2012, National enhanced elevation assessment: Fairfax, Virginia, 84 p., accessed April 18, 2018, at http://www.dewberry.com/docs/default-source/documents/ neea_final-report_revised-3-29-12.pdf? sfvrsn $=0$.

Esri, Inc., 2018, ArcGIS: Esri, Inc. website, accessed May 3, 2018, at https://www.esri.com/software/arcgis/.

Federal Emergency Management Agency (FEMA), 2018a, Flood insurance study, Morgan County Colorado, and incorporated areas; effective April 4, 2018: Washington, D.C., Federal Emergency Management Agency, 35 p., 6 pl.

Federal Emergency Management Agency (FEMA), 2018b, FEMA Flood Map Service Center: Federal Emergency Management Agency website, accessed April 18, 2018, at https://msc.fema.gov/portal/.

Follansbee, R., and Sawyer, L.R., 1948, Floods in Colorado: U.S. Geological Survey Water-Supply Paper 997, 151 p. [Also available at https://doi.org/10.3133/wsp997.]

Homer, C.G., Dewitz, J.A., Yang, L., Jin, S., Danielson, P., Xian, G., Coulston, J., Herold, N.D., Wickham, J.D., and Megown, K., 2015, Completion of the 2011 national land cover database for the conterminous United StatesRepresenting a decade of land cover change information: Photogrammetric Engineering and Remote Sensing, v. 81, no. 5, p. 345-354. [Also available at https://doi.org/10.1016/ S0099-1112(15)30100-2.]

Kimbrough, R.A., and Holmes, R.R., Jr., 2015, Flooding in the South Platte River and Fountain Creek basins in eastern Colorado, September 9-18, 2013: U.S. Geological Survey Scientific Investigations Report 2015-5119, 33 p., accessed March 2018 at https://doi.org/10.3133/sir20155119.

Kohn, M.S., 2017, Cross-section data and pressure transducer location of the South Platte River near Fort Morgan, Colorado, 2017: U.S. Geological Survey data release, https://doi.org/10.5066/F7XG9PN1.
Kohn, M.S., 2018, Geospatial data and surface-water model archive for a flood-inundation mapping study of the South Platte River at Fort Morgan, Colorado, 2018: U.S. Geological Survey data release, https://doi.org/10.5066/P9YA4STZ.

Matthai, H.F., 1969, Floods of June 1965 in the South Platte River basin, Colorado: U.S. Geological Survey WaterSupply Paper 1850-B, 64 p., 4 pls. [Also available at https://doi.org/10.3133/wsp1850B.]

National Weather Service [NWS], 2018a, South Platte River at Fort Morgan, Co: National Weather Service Advanced Hydrologic Prediction Service website, accessed April 17, 2018, at https://water.weather.gov/ahps2/hydrograph. php? wfo=bou\&gage $=$ fomc 2 .

National Weather Service [NWS], 2018b, National Weather Service glossary: National Weather Service web page, accessed April 17, 2018, at http://w1.weather.gov/glossary/ index.php?word=action+stage.

Onset Computer Corporation, 2018, HOBOware user's guide: Pocasset, Mass., Onset Computer Corporation, 226 p., accessed August 21, 2018, at http://www.onsetcomp.com/ files/manual_pdfs/12730-Z\%20HOBOware\%20 User\%27s\%20Guide.pdf.

Rantz, S.E., and others, 1982, Measurement and computation of streamflow; Volume 1. Measurement of stage and discharge: U.S. Geological Survey Water-Supply Paper 2175, 284 p. [Also available at https://doi.org/10.3133/wsp2175_vol1.]

U.S. Army Corps of Engineers [USACE], 2011, HEC-GeoRAS - GIS tools for support of HEC-RAS using ArcGIS—User's manual (ver. 4.3.93, February 2011): U.S. Army Corps of Engineers, [variously paged].

U.S. Army Corps of Engineers [USACE], 2016a, HEC-RAS - River analysis system-Hydraulic reference manual (ver. 5.0, February 2016): U.S. Army Corps of Engineers, [variously paged].

U.S. Army Corps of Engineers [USACE], 2016b, HEC-RAS - River analysis system - User's manual (ver. 5.0, February 2016): U.S. Army Corps of Engineers, [variously paged].

U.S. Army Corps of Engineers [USACE], 2018, National levee database: U.S. Army Corps of Engineers database, accessed April 18, 2018, at http://nld.usace.army.mil/egis/f?p=471:1.

U.S. Census Bureau, 2018, American FactFinder: U.S. Census Bureau database, accessed April 18, 2018, at http://factfinder2.census.gov.

U.S. Department of Agriculture Farm Service Agency, 2015, National agricultural imagery program, NAIP15: U.S. Department of Agriculture Farm Service Agency web mapping service, accessed March 12, 2018, at http://www.arcgis.com/home/webmap/viewer.html?webmap $=03 \mathrm{e} 5 \mathrm{dfa} 695 \mathrm{~b} 24 \mathrm{a} 48 \mathrm{bf} 5 \mathrm{f} 5 \mathrm{bf} 14 \mathrm{c} 633416$. 
U.S. Geological Survey [USGS], 2018a, USGS 06759500 South Platte River at Fort Morgan, CO, in Water data for the nation: U.S. Geological Survey National Water Information System database, accessed April 17, 2018, at https://doi.org/ 10.5066/F7P55KJN. [Site information directly accessible at https://waterdata.usgs.gov/co/nwis/uv?site_no=06759500].

U.S. Geological Survey [USGS], 2018b, USGS flood inundation mapping program: U.S. Geological Survey website, accessed April 18, 2018, at https://water.usgs.gov/osw/flood_inundation.

U.S. Geological Survey [USGS], 2018c, The StreamStats program: U.S. Geological Survey website, accessed April 18, 2018, at https://streamstats.usgs.gov/ss/.

U.S. Geological Survey [USGS], 2018d, USGS 3D elevation program: U.S. Geological Survey website, accessed April 19, 2018, at https://nationalmap.gov/3DEP/. 
For more information, contact Director, Colorado Water Science Center U.S. Geological Survey

Box 25046, MS-415

Denver, CO 80225

http://co.water.usgs.gov/ 


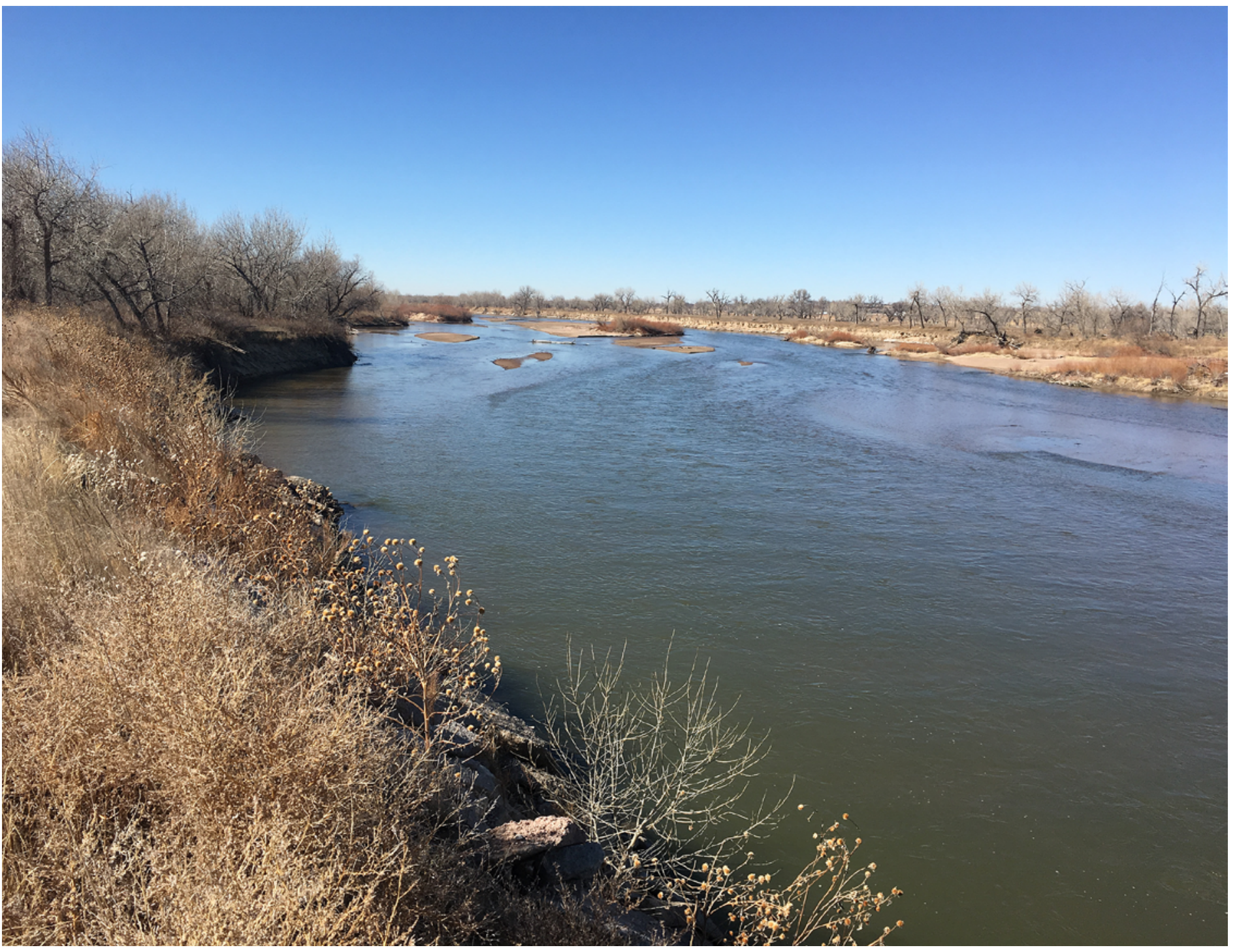

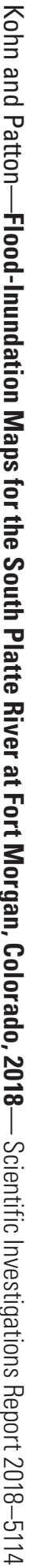

